九州大学学術情報リポジトリ

Kyushu University Institutional Repository

\title{
DISCOVERY OF THE GENUS AENIGMATIAS MEINERT FROM JAPAN, WITH A REDESCRIPTION OF A. DORNI (ENDERLEIN) (DIPTERA, PHORIDAE)
}

Goto, Tadao

Takeno, Koichi

https://doi.org/10.5109/2442

出版情報: ESAKIA. 20，pp.139-148，1983-12-15. Entomological Laboratory，Faculty of Agriculture, Kyushu University バージョン：

権利関係 : 


\title{
DISCOVERY OF THE GENUS AENIGMATIAS MEINERT FROM \\ JAPAN, WITH A REDESCRIPTION OF A. DORNI \\ $(\text { ENDERLEIN) (DIPTERA, PHORIDAE })^{1, \cdot 2)}$
}

\author{
T A D а GoTô \\ Entomological Laboratory, Faculty of Agriculture, \\ Kyushu University, Fukuoka 812, Japan \\ and

\section{KÔICHI TAKENO} \\ Hikosan Biological Laboratory, Faculty of Agriculture, \\ Kyushu University, Hikosan, Fukuoka 824-07, Japan
}

\begin{abstract}
Aenigmatias dorni (Enderlein) is redescribed and illustrated based on the Japanese specimens. This is the first record of the genus from Japan. A new morphological interpretation of the female terminalia is also proposed.
\end{abstract}

The genus Aenigmatias Meinert, 1890 is the only representative of the subfamily Aenigmatiinae in the Holarctic Region. At present this genus comprises 6 European and 6 North American species. No species of the genus, however, has been recorded from Japan.

From 1968 to 1973 the junior author (KT) had set up a Malaise trap in the garden of the Hikosan Biological Laboratory, Kyushu University which is located on the median slope of Mt. Hikosan $(1,200 \mathrm{~m})$, Fukuoka Pref., Kyushu. He made a large collection of phorid flies together with many other insects. The senior author, whom these flies were entrusted to for taxonomic study, found many specimens representing a single species of Aenigmatias among them. This species runs to European A. dorni (Enderlein) in Schmitz's (1955) key to Palearctic Aenigmatias, and it fits the description of dorni made by him.

In the course of the study, the authors realized Schmitz's description of the species is inadequate in regard to the critical characters such as thorax and male genitalia, and is erroneous in the interpretation of the female ter-

1) Contribution from the Entomological Laboratory, Faculty of Agriculture, Kyushu University, Fukuoka (Ser. 3 No. 137).

2) Contribution from the Hikosan Biological Laboratory, Faculty of Agriculture, Kyushu University, Hikosan. (Ser. 3 No. 3). 
minalia. For these reasons the authors will redescribe A. dorni in this paper, based on the Japanese specimens. An alternative to Schmitz's interpretation of the female terminalia will be also proposed.

Among the Holarctic phorid flies the genus Aenigmatias is easily recognized by a combination of the following characters: (male) frons broad, hairy; first antennal segment enlarged; proboscis very small; mesoanepisternum projected laterally on its posterodorsal $1 / 4$, thus possessing dorsal and ventral surfaces, the dorsal one hairy and visible from above ; vein Rs short haired; Vein $R_{2}$ present; and fore tibia with 1 , mid and hind tibiae with 3 hair-seams respectively : (female) apterous ; compound eye reduced; ocellus absent; thorax trapezoidal in dorsal view; scutellm absent ; and wing reduced into a membraneous projection.

The members of the subfamily Aenigmatiinae are known to be myrmecophilous or termitophilous. The Aenigmatias species are associated especially with the ants of the genus Formica. The European species A. lubbockii(Verrall) was reported to emerge from the pupae of Formica fusca Linnaeus and $F$. picea Nylander (Schmitz, 1955, Disney, 1979 after Donisthorpe, 1927). A. dorni (Enderlein) has been sometimes found in the nests of $F$. rufibarbis Fabricius and $F$. glebaria Nylander in Europe. Although the hosts of this species has not been known in Japan, $F$. japonica Motschulsky and $F$. sp. (undescribed species) are distributed in Kyushu (Sonobe, 1977), and the both or either of these species appear to be host of dorni.

Before going further the authors wish to express their sincere thanks to Prof. Y. Hirashima and Assoc. Prof. K. Morimoto of the Entomological Laboratory, Kyushu University for their kind guidances and encouragements. They are also much indebted to Prof. T. Saigusa of the Biological Laboratory, Kyushu University for his critical reading of the manuscript and valuable suggestions in taking photographs. Their cordial thanks are due to Assoc. Prof. M. T. Chûjô of the Hikosan Biological Laboratory, Kyushu University for his kind permission to examine the phorid flies of the laboratory and his constant encouragement.

\section{Aenigmatias dorni (Enderlein)}

O niscomyia dorni Enderlein, 19013, Zool. Jahrb. Syst., 27: 151.

A enigmatias dorni:Schmitz, 1914, Zool. Jahrb. Syst., 37: 544.

Platyphora dorni: Schmitz, 1915, Deutsch. Ent. Zeitschr.. 472.

A enigmatias dorni: Schmitz, 1927, Nat. Maandbl., 16: 93.

Male. Compound eye bare. Frons yellowish brown, subshining, broad, 0.60-o. 65 of head width, 1.6-1. $8 \times$ as wide as long, entirely short haired. Chaetotaxy: Ocellar triangle with 2 short setae; each side of anterior ocellus with a short seta; each vertical border with 3 short setae, outer one of which is inserted near eye margin. Gena bearing a series of about 8 short bristly 


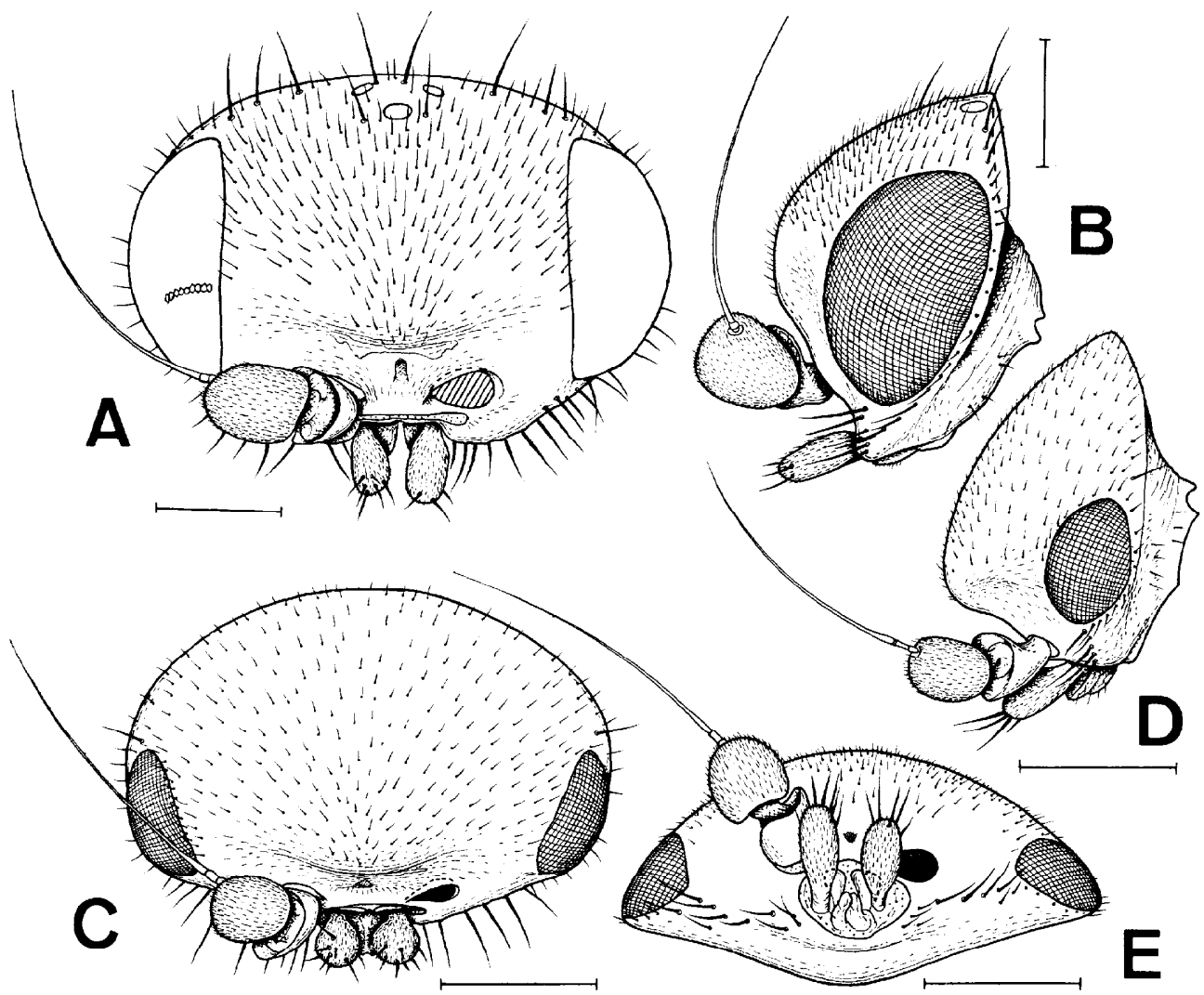

Fig. 1. Head of Aenigmatias dorni (Enderlein). A : Male head in frontal view. B : Ditto in lateral view. C: Female head in frontal view. D: Ditto in lateral view. E : Ditto in ventral view. Scale: $0.2 \mathrm{~mm}$.

hairs from lower eye margin to oral margin. Antenna yellowish brown, thinly grayish brown pollinose; 1st antenna1 segment enlarged, as long as 3rd, thickened distally; 3rd antenna1 segment globose, as long as wide, flattened dorsally ; arista subapical, about $5 \mathrm{x}$ as long as 3rd antenna1 segment, bare. Palpus yellowish brown, thinly grayish brown pollinose, slightly longer than $2 \mathrm{x}$ as long as wide, bearing 4-6 short bristles on distal portion. Proboscis small; clypeus divided into 2 lateral plates by median membranization ; labrum very small; labellum small.

Thorax distinctly wider than head. Scutum brown, subshining, wider than long, short setulose, with 2-3 short setae (dorsocentral setae) on posterolateral portion, humeral seta absent. Scutellum brown, thinly grayish brown pollinose, with 4-10 short bristly hairs on each posterolateral margin. Pleura shining brown ; mesoanepisternum projected laterally on its posterodorsal $1 / 4$, thus possessing dorsal and ventral surfaces, the dorsal one visible from above, hairy and bearing 1 short bristle at its posterior margin. Anterior 


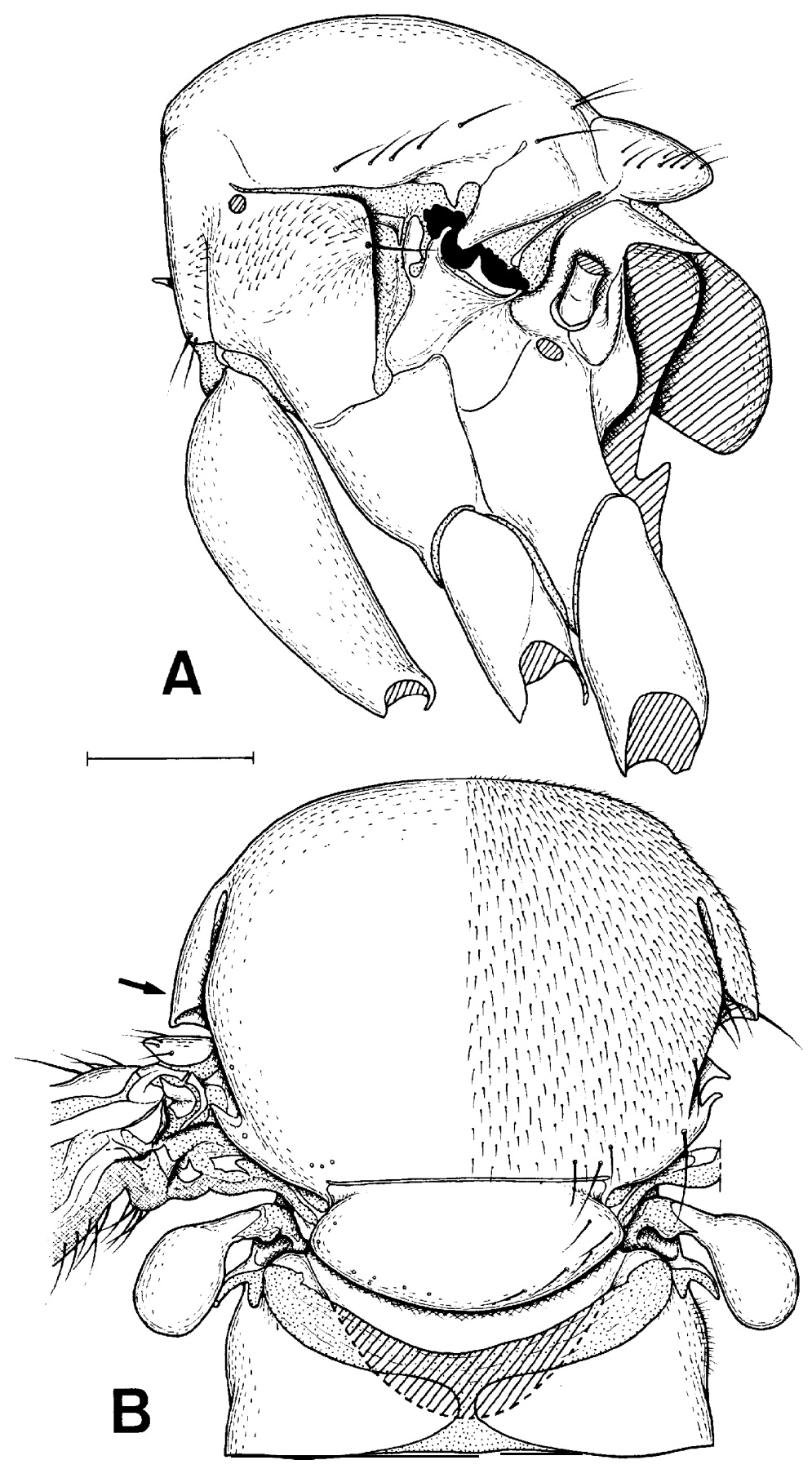

Fig. 2. Male thorax of Aenigmatias dorni (Enderlein). A : Lateral view. B : Dorsal view. Arrow indicating laterally projected mesoanepisternum. Scale : $0.3 \mathrm{~mm}$. 
basalare narrow and connected with posterodorsal portion of mesoanepisternum. Membraneous area between scutellum and postnotum broad.

Wing hyaline, slightly tinged with brownish gray; all veins brown, A, sometimes yellow. Costa moderately long, costal index 0.49-o. 51; combined length of 2 nd and $3 \mathrm{rd}$ costal sectors 0.37 -o. 48 of 1 st in length; 3rd costal sector as long as 2 nd. Vein $R_{2}$ narrow. Vein $M_{1}$ curved anteriorly, disappearing and not deflected at distal extreme. Vein $\mathrm{M}_{2}$ curved anteriorly on proximal $2 / 3$, then very weakly curved posteriorly or sometimes almost straight, evanescent at apex. Vein $\mathrm{M}_{3-4}$ bisinuate, complete to wing margin. Vein $\mathbf{A}$, weak, almost straight, disappearing on about distal $1 / 6$, sometimes complete to wing margin. Costa1 cilia short, $1.5-2$. Ox as long as width of 1 st costal sector; vein Rs with 19-29 short hairs ; axillary margin with 6-7 hairs ; wing membrane entirely trichose. Halter brown.

Fore coxa, fore femur, all tibiae and tarsi brown; mid coxa shining brown; mid femur brownish yellow on proximal $1 / 2$, then gradually darkened distally; hind coxa and proximal $2 / 3$ of hind femur pale yellow, the rest of the femur yellowish brown. Fore tibia stout, shorter than 1st and 2nd tarsomeres together, with 1 dorsal hair-seam and about 7 short bristly hairs on ventrodistal portion ; fore tarsus dilated and flattened, gradually narrowed distally; 1 st tarsomere as wide as tip of fore tibia, sometimes slightly wider, 0.78-0.85 of fore tibia in length; 2nd tarsomere $1 / 2 \times$ as long as 1 st; 4th and 5th tarsomeres subequal in length. Mid tibia bearing anterodorsal, dorsal and posterodorsal hair-seams, the dorsal one disappearing on distal $1 / 3$ of the tibia, with 2-5 short bristly hairs ventrodistally. Hind tibia bearing 3 hair-seams as in mid tibia, but dorsal one complete to tip of the tibia, with 2-3 short bristly hairs ventrodistally.

Abdomen oval in doral view, widest at 2nd tergum. All terga blackish brown, subshining, thinly grayish brown pollinose, minutely haired, distinctly wider than long, e. g., 2nd tergum $6 \mathrm{x}$ as wide as long; 1st tergum shortened toward median portion where it is membranized; 3rd to 5th terga with more or less concave posterior margins; 6th tergum with concave anterior margin.

Male genitalia mostly retracted under 6th tergum, shining yellowish brown, small, asymmetrical in structure. Epandrium large, broad on right side, bearing 2 pairs of forceps and hook-like process at right posteroventral corner, weakly membraneous on posterior $1 / 2$ of right side. Left upper forceps weakly tapering toward tip, rounded on posterior margin, short haired; left lower forceps thickened, wider and longer than upper one, rounded distally, sparsely short haired; right upper forceps thick, oriented inwardly and pointed distally, with short bristly hairs; right lower forceps short and broad, triangular in shape, weakly membranized, sparsely short haired, with rounded distal margin. Hypandrium fused with epandrium on its proximal portion, broadly membraneous except for distal $1 / 4$; its lateral margins connected with each other by a 


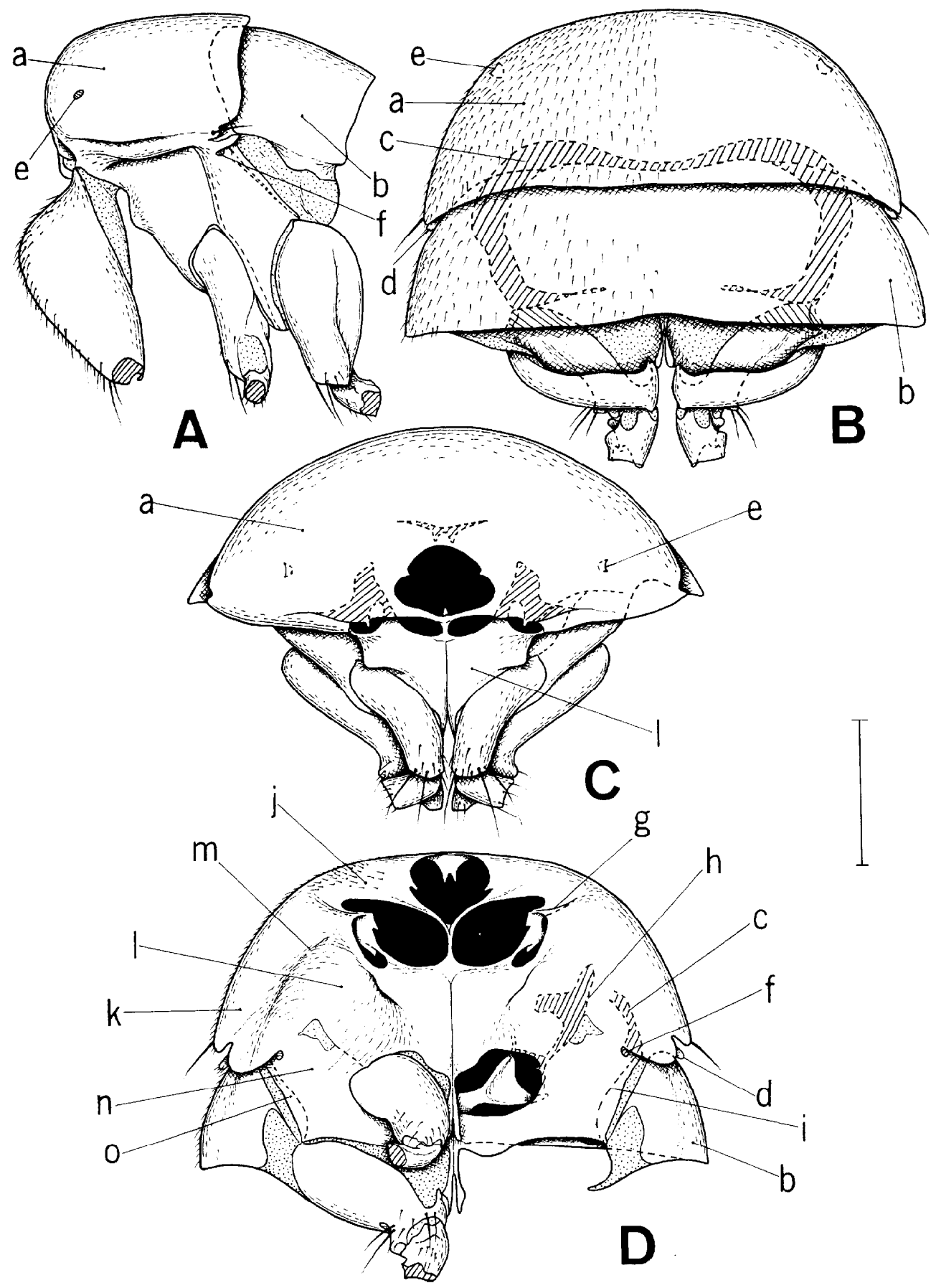

Fig. 3. Female thorax and 1st abdominal segment of Aenigmatias dorni (Enderlein). A : Lateral view. B: Dorsal view. C: Frontal view. D : Ventral view. a, mesonotum; b, 1 st abdominal tergum ; c, postnotum; d, rudiment of wing; e, spiracle 2; $\mathrm{f}$, spiracle $3 ; \mathrm{g}$, pleural suture $1 ; \mathrm{h}$, pleural suture 2 ; $\mathrm{i}$, pleural suture $3 ; \mathrm{j}$, prothorax; $\mathrm{k}$, mesoanepisternal area ; 1 , mesokatepisternal area; $m$, anapleural suture (?); n, metepisternal area; 0, metepimeron. Scale : $0.3 \mathrm{~mm}$. 


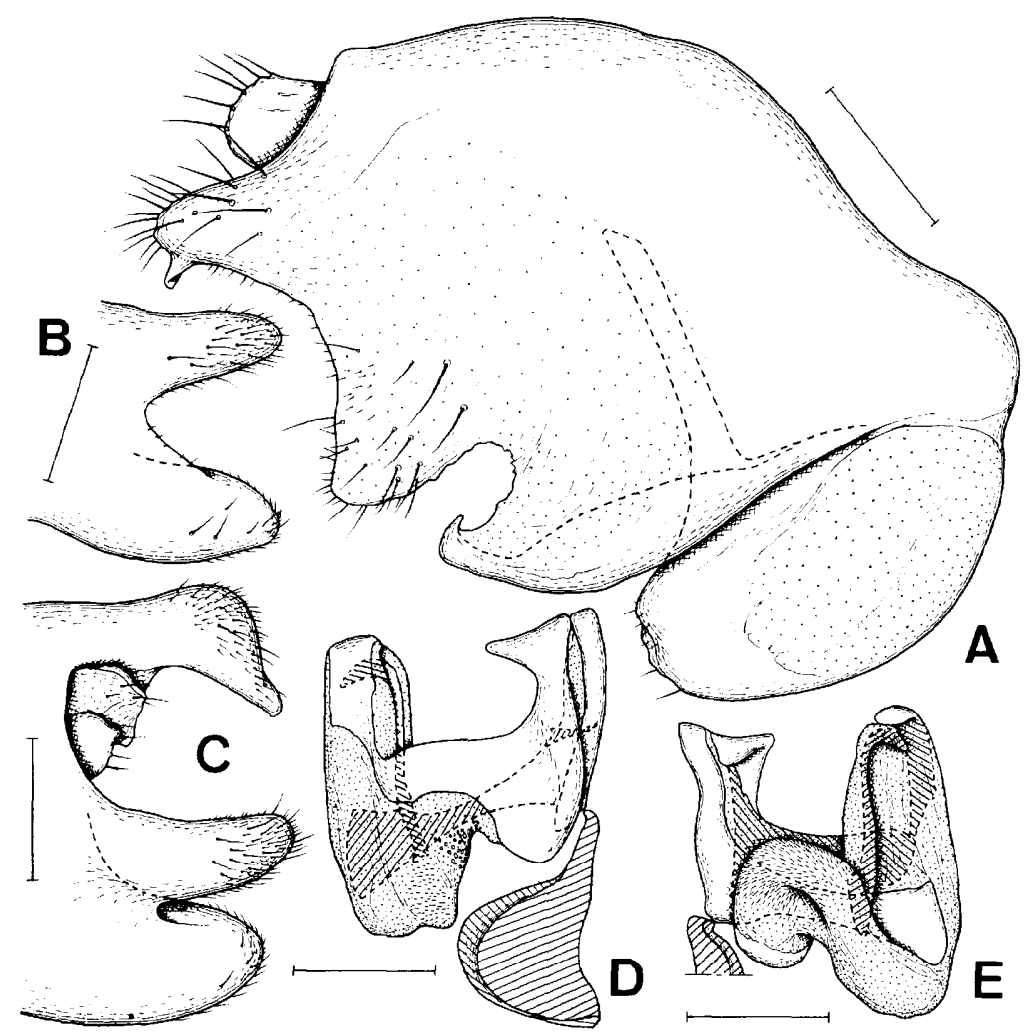

Fig. 4. Male genitalia of Aenigmatiasdorni (Enderlein). A : Male genitalia in lateral view. B : Left forceps in lateral view. C : Epandrium in dorsolateral view. D : Aedeagus in right lateral view. E : Ditto in left lateral view. Scale: $0.1 \mathrm{~mm}$,

narrow arched arm, thus the hypandrium ringed in structure. Aedeagus composed of following 3 sclerites; ringed sclerite occupying proximal portion of aedeagus, the sclerite with a narrow, long expansion from its posterior ven. trolateral margin on left side ; broad flat sclerite lying on right lateral portion of aedeagus, narrowed toward tip and extending dorsally as in Fig. 4 D; slender sclerite lying on distal portion of aedeagus. Ejaculatory apodeme present, slender and short. Gonopore opening at membraneous ventrodistal portion of aedeagus.

Body length :2.2-2.5 mm.

Female. Differing from male as follows. Head compressed. Compound eye reduced, about $2 / 5$ of head height. Ocellus absent. Frons brownish yellow, thinly gray pollinose, broader than in male, 0.74-0.77 of head width, entirely bearing pale yellow minute hairs, without setae. Third antenna1 segment yellow, slightly tinged with orange; arista pale yellow. Palpus yellow.

Mesonotum yellowish brown, trapezoidal in dorsal view, possessing meso- 
thoracic spiracle at anterolateral portion, entirely minutely haired and bearing 1 short bristle at each posterolateral corner. Lateral part of thorax brownish yellow, shining, bare ; mesokatepisternal area concaved, producing into a small projection at its anterodorsal portion; mesoanepisternal area extending laterally and continued to mesonotum. Scutellum absent. Postnotum very short, completely concealed. Apterous, wing reduced into a minute membraneous projection. Halter absent.

Legs brownish yellow in ground color, hind tibia and hind tarsus more darkened; hind femur pale yellow on proximal $3 / 5$, the rest darkened. Fore femur stout, $2.2 \times$ as long as wide ; fore tibia as long as 1st to 4th tarsomeres together, $2.4 \times$ as long as wide. Fore tarsus narrower than tip of fore tibia; 1st tarsomere slightly longer than wide, 1.6 of 2nd tarsomere in length ; 2nd to 5th tarsomeres with same width, narrower and shorter than 1st; 2nd tarsomere as long as wide ; 3rd and 4th tarsomeres slightly shorter than 2nd; 5th tarsomere as long as 2nd. Mid femur slenderer than fore and hind femora, $3.3 \sim$ as long as wide. Hind femur $2.4 \times$ as long as wide.

Abdomen broad, narrowed posteriorly; all terga except for 5th yellowish brown, grayish brown pollinose, entirely minutely haired except for anterior marginal portions ; 5th tergum yellow, bare and membraneous except for yellowish brown posterior marginal and minutely haired lateral portions. All terga distinctly wider than long, e. g., 1st tergum $5 \mathrm{x}$ as wide as long; 2nd and 6th terga longest, the other terga with same length; 1st to 4th terga rectangular in shape, with straight anterior and posterior margins, 5th and 6th terga with concave anterior margin and convex posterior one. Terminalia

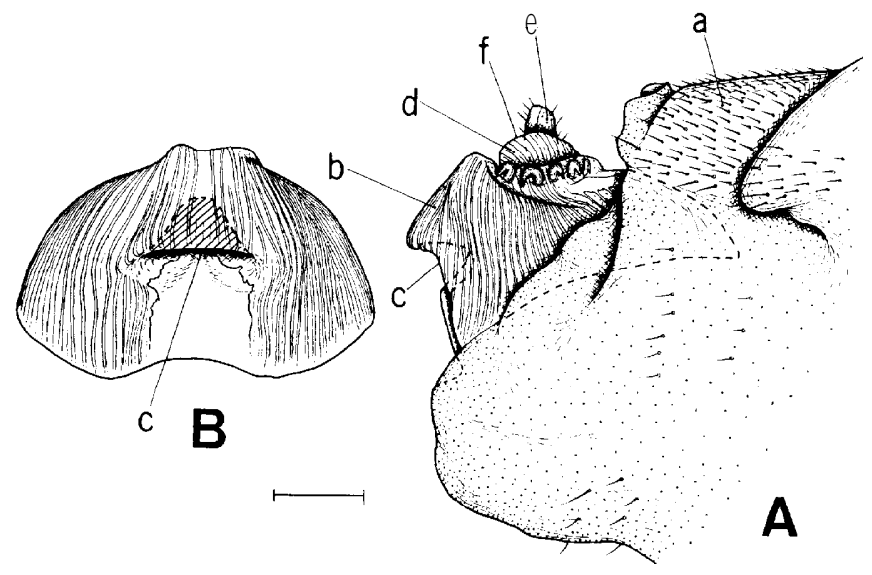

Fig. 5. Female terminalia of Aenigmatiasdorni (Enderlein). A : Terminalia in lateral view. B : Seventh abdominal segment in ventral view. a, 6th abdominal tergum; b, 7th abdominal segment; c, pouch ; d, 8th abdominal segment; e, 9+10th abdominal segment; f, opening of gonopore. Scale : $0.2 \mathrm{~mm}$. 
short, highly specialized : Seventh segment (Fig. 5 b) with many longitudinal sclerotized stripes except for its dorsal portion and weakly sclerotized pentagonal sternum on proximal $1 / 2$ of its ventral portion; the segment possessing a pair of crescent-shaped sclerites on dorsal surface near posterior margin, bearing about 17 stout hook-like spines along its posterior margin, and also carrying a pouch* (Fig. 5 c) on middle of ventral surface just behind the pentagonal sclerite, the pouch bearing a weakly sclerotized triangular
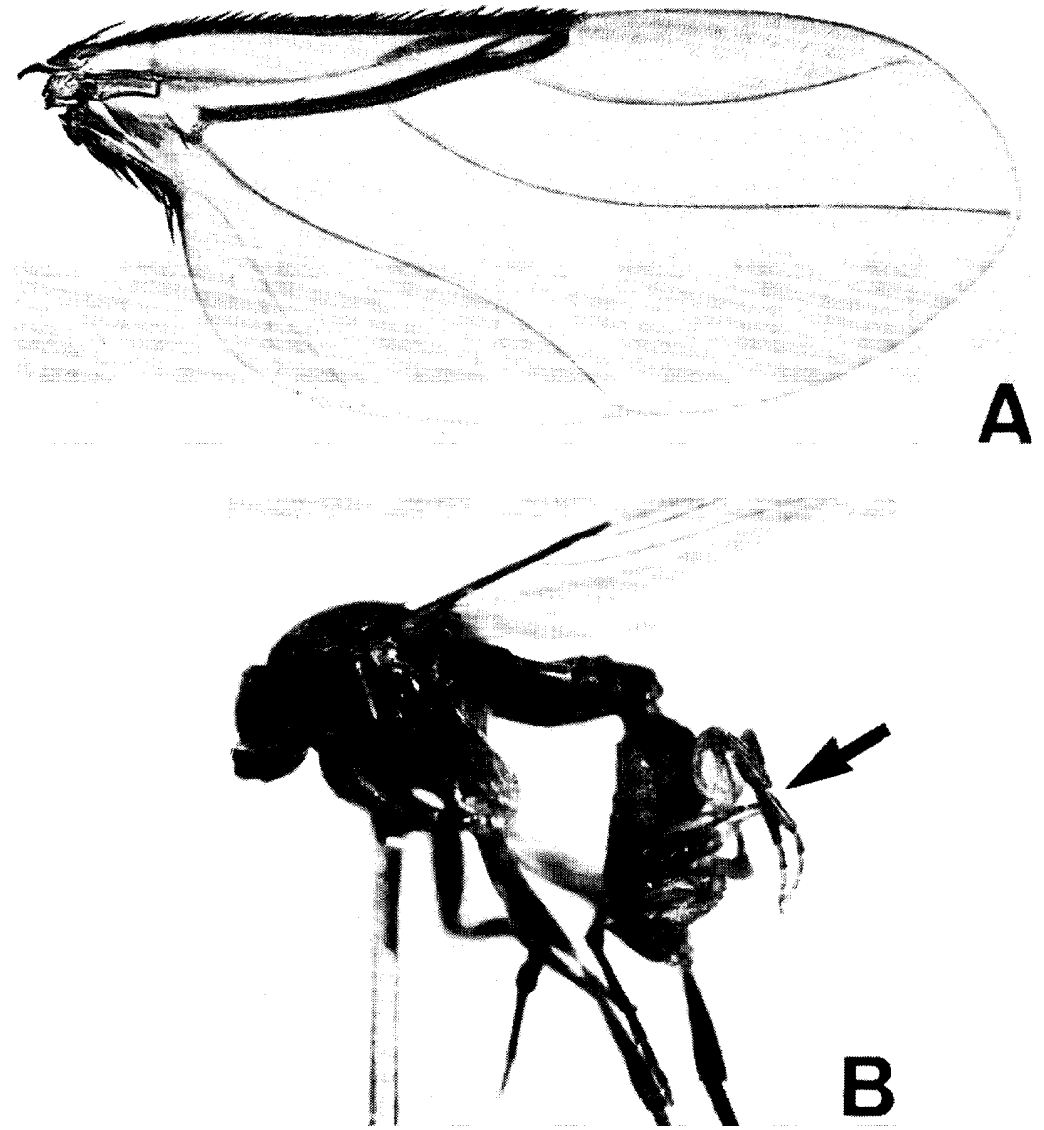

Fig. 6. Aenigmatias dorni (Enderlein). A : Male wing. B : Male and female (black arrow) adults in copula.

This pouch is used to receive the upper pair of forceps of the male genitalia in copulation. Schmitz (1955) erroneously regards the opening of the pouch as gonopore, thus the striped segment carrying it as the 8th segment (refer to p. 367 and textfig. 211 in Die Fliegen). The true gonopore opens on his $9+10$ th segment. Consequently Schmitz's 8 th, $9+10$ th segments and cercus should be reasonably revised as 7 th, 8 th and $9+10$ th segments respectively, The 7 th segment of Schmitz is considered to be the intersegmental area between the 6 th and 7 th segments. 
plate (Enderlein's subgenital plate) on its inner side. Eighth segment (Fig. 5 d) small and short, with gonopore on its caudal portion. Ninth+tenth segment (Fig. 5 e) very small, oblong, with short hairs. Cercus absent.

Body length: about $1.5 \mathrm{~mm}$.

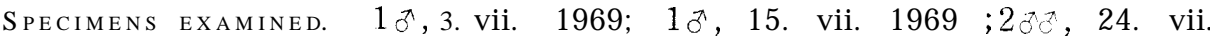
$1970 ; 1$ 후 (in copula), 30. vii. 1970; 2ðð, 31. v. $1970 ; 1 \S, 4$. viii. 1970 ; $1 \precsim, 5$. viii. $1970 ; 1 \precsim, 8$. viii. $1970 ; 1 \precsim 1$ क (in copula), 10. viii. 1970; 1ð,11. viii. 1970; 1 ð, 8. ix. $1970 ; 1 \precsim 1$ 우 (in copula), 17. vii. $1972 ; 1 \precsim, 18$. vii. $1972 ; 1$ \$1 우 (in copula), 27. vii. $1972 ; 1$ б, 1. viii. $1972 ; 2302$ 우우 (2 pairs in copula), 26. vii. 1973. All were collected by $K$. Takeno with a Malaise trap at Mt. Hikosan (700 m), Fukuoka Pref., Kyushu.

Remarks. Aenigmatias dorni (Enderlein) is very similar to A. lubbockii (Verrall, 1877). According to Schmitz (1955), the former is distinguished from the latter in having the following characters; vein $M_{1}$ not deflected at extreme tip, vein $\mathrm{M}_{2}$ more or less curved in \$-shape, vein $\mathrm{A}$, longer and female 5th abdominal tergum membranized and bare except for its lateral and posterior portions. In the males of Japanese material the vein $\mathrm{M}_{2}$ is sometimes almost straight on its distal $1 / 2$. Delage \& Lauraire (1971) discuss the characters distinguishing the both species.

In Japan A. dorni is presently known from Mt. Hikosan only, where the adults appear in July and August. It is interesting that all females were caught in copula. This probably indicates that the female is dispersed by the male. The mating pair in flight has been observed in Europe (Schmitz, 1955).

\section{References}

Borgmeier, 'I'. 1963. Revision of the North American Phorid Flies. Part I. The Phorinae, Aenigmatiinae and Metopininae except Megaselia (Diptera, Phoridae). Studia Ent., 6: $l-256$.

Delage, A., \& M.-C. Lauraire, 1971. A propos de deux Aenigmatiinae (Dipt., Phoridae) nouvelles pour la faune de France. Entomologists, $27: 159-162$.

Disney, R. H. L. 1979. Natural history notes on some British Phoridae (Diptera) with comments on a changing picture. Entomologist's Gaz., 30: 141-150.

Schmitz, H. 1927. Revision der Phoridengattungen, mit Beschreibung neuer Gattungen und Arten. Nat. Maandbl., 16: 93-94.

- 1929. Revision der Phoriden. Berlin und Bonn, F. Duemmler, 211 pp.

- 1955. Phoridae, in Lindner, Die Fliegen der palaearkt. Region, 33: 321-368.

- 1956. Ditto, Ibid., 33: 369-416.

Sonobe, R. 1977. Formicidae of Japan. (3) Genus Formica Linnaeus. Ari, (8) : 1-2. (In Japanese) 